\title{
Vegetative anatomy of Finschia Warb. and its place in Hakeinae ${ }^{\ddagger}$ (Proteaceae)
}

\author{
D.M. Catling ${ }^{\dagger}$
}

\begin{abstract}
D.M. Catling Durham University, Department of Biological Sciences, South Road, Durham DHI $3 L E$
\end{abstract}

\begin{abstract}
The leaf anatomy of three species of Finschia included in the subtribe Hakeinae (Proteaceae) is described. The stem-node-leaf continuum is described in F. chloroxantha Diels and F. rufa Warb.. Within the genus, features of the leaf epidermis make it possible to distinguish species and are consistent with synonymy between F. rufa and F. carrii (Sleumer) C.T.White. Anatomical characteristics are compared with those of Grevillea and Hakea and similarities that might support relationships are discussed.
\end{abstract}

\section{Introduction}

Finschia comprises three Papuasian species and is currently recognised as a member of tribe Embothrieae, subtribe Hakeinae (Proteaceae) (Weston \& Barker 2006). All Finschia species are trees with buttressed trunks, often raised on stilt roots. Finschia ferruginiflora is restricted to the Eastern Highlands and Western Highlands of Papua New Guinea; Finschia rufa is known from Madang, Morobe, Eastern Highlands and Western Highlands, Central and Milne Bay districts of Papua New Guinea (Foreman 1995); and Finschia chloroxantha is more widely distributed in Papua New Guinea (Conn \& Damas 2006+) and extending to the Aru Islands, Solomon Islands, New Hebrides and Palau Islands.

Finschia Warb. was circumscribed by Warburg (1891) but became the object of controversy in the first half of the twentieth century. Lauterbach (1913) distinguished Finschia from Grevillea R.Br. but Diels (1916) rejected the separation of the two genera on the grounds that, although characters of the fruits were described, fruits of neither F. rufa nor F. chloroxantha had been seen. Sleumer (1939) included Finschia in Grevillea R.Br. and gave a key to the New Guinea species. White (1949) revised the genus, amended Warburg's description, described a new species and proposed a new combination. He delimited four species, F. rufa Warb., F. carrii (Sleumer) C.T.White, F. ferruginiflora C.T. White and F. chloroxantha Diels but Foreman (1995) subsequently decided that F. rufa and F. carrii were synonymous.

¥In the original title this was cited as "Grevilleeae" but the editorial committee chose to use the more recent classification of Weston and Barker (2006) on the recommendation of the referees. ${ }^{\dagger}$ died $15^{\text {th }}$ April, 2005 
The wood anatomy of Finschia has been reported on in general works (Furuno 1977, Ilic 1991, Metcalfe \& Chalk 1950, Streimann 1969). Chattaway (1948) included the genus in her study of the wood anatomy of the Proteaceae but no account of the leaf and nodal anatomy of Finschia has been published.

A list of the specimens studied, including details of collectors and locations, is given in appendix A.

\section{Methods}

Methods were those used to study the anatomy of leaves and nodes of Hakea (Catling \& Gates 1995a, b). Material of herbarium specimens was reconstituted by boiling in water for 10 minutes, and mounted in a split cork and sections $20 \mu \mathrm{m}$ thick cut using a Reichert OME microtome. Sections were cleared in sodium hypochlorite solution, stained with safranin and alcian blue, dehydrated in a graded alcohol series, cleared in Histoclear and mounted in DePex or Canada Balsam.

\section{Observations}

\section{Finschia chloroxantha}

\section{Stem}

Stems included in the stem-node-leaf continuum measured 3-4 $\mathrm{mm}$ in diameter and were surrounded by 5-6 layers of superficial cork. The epidermis was disrupted. The cortex was 5-11 cells wide, complementing the size of fibre caps associated with vascular bundles; mostly unlignified but contained some lignified cells and groups of large sclereids; some cells contained tannin. There was a more or less continuous ring of pericyclic sclerenchyma. As well as fibres, this included sclereids which often, though not necessarily, coincided with medullary rays. Vascular tissues were eustelic to weakly siphonostelic and a continuous cambial zone was recognisable. There were interxylary fibres. Pith was lignified and included many large groups of sclereids, especially near developing leaf traces.

\section{Node}

Leaf traces spanned only a short distance between the stele and the petiole. They did not extend into adjacent nodes. Traces were recognised by increased numbers of vessels in stelar bundles. At higher levels, modified xylem consisted of simple vascular elements and unlignified parenchyma. Below nodes, near leaf traces, stelar bundles divided and merged. Outside the leaf traces, the cortex was wider and enclosed numerous sclereids.

In the specimen collected by Powell, ten nodes were examined. Lateral traces and eight median traces were continuous with single stelar bundles. In two nodes, in the median position, two stelar bundles were modified. In three nodes examined in BSIP5577, there was a single stelar bundle associated with each lateral trace. In one node, in the median position, there was a complex of three bundles. In one of the nodes in NGF9123, there was a single modified stelar bundle in the position of each lateral leaf trace, in the other, there were four on one side and three on the other. In the median position, three or six bundles were modified. 


\section{Leaf base}

Leaves were petiolate.

The base of the petiole was first recognised by an absence of cork and by an abscission layer within the stem (Fig. 1). In fibre caps associated with leaf traces, cells were dispersed and mixed with parenchyma (Fig. 1). No sclerenchyma crossed the abscission layer. Towards the lamina there were increased amounts of lignified parenchyma and fibres within the petiole and, where the median leaf trace crossed the abscission layer, there was a weakly-developed fibre cap ahead of it (Fig. 1). Above this, the trace divided and there was a fibre cap associated with each brand. Lateral leaf traces were within the cortex.

At this level, within the stele, one or two small bundles on either side of the median leaf gap had modified xylem. At higher levels, they passed into the petiole where they were inversely orientated and completed a ring of vascular bundles.

Lateral leaf traces entered the petiole. Near the abscission layer, they branched and some tissues formed small vascular bundles on the margins of the leaf base, outside the main circle. There were numerous sclereids in the petiole and in the cortex of the stem, many in a broken line close to the adaxial side of the abscission layer (Fig. 2).

Where the petiole became separate from the stem, it contained a ring of small bundles. Bundles in the abaxial arc had well developed abaxial fibre caps and smaller groups of adaxial fibres. Small groups of abaxial and adaxial fibres were associated with each inverted bundle. Towards each margin there were two or three closely associated small bundles (Fig. 3).

\section{Petiole}

Towards the lamina, lateral bundles and bundles towards the abaxial surface were in a broad arc. Abaxial fibre caps were partially merged; adaxial fibres were in discreet groups.

Towards the adaxial side, in three of the five specimens examined, there were well defined inverted bundles (Fig. 4). In material collected by Powell and in NGF 9123, groups of vascular tissues were less precisely orientated. In material collected by Powell, these vascular groups were not seen in the distal region of the petiole; occasional vascular elements occurred among adaxial fibres.

At lower levels towards the base of the petiole, there were adaxial and abaxial fibres associated with each inverted group of vascular tissues. At higher levels, there was a continuous band of adaxial fibres.

\section{Transition from petiole to leaf}

Towards the distal end of the petiole, there were 2 adaxial marginal extensions. Two lateral bundles were separated from the main arc by unlignified parenchyma (Fig. 5).

In BSIP5577 and Akorra 238, inverted bundles occurred in lower levels of the leaf although they were not seen at the centre. 

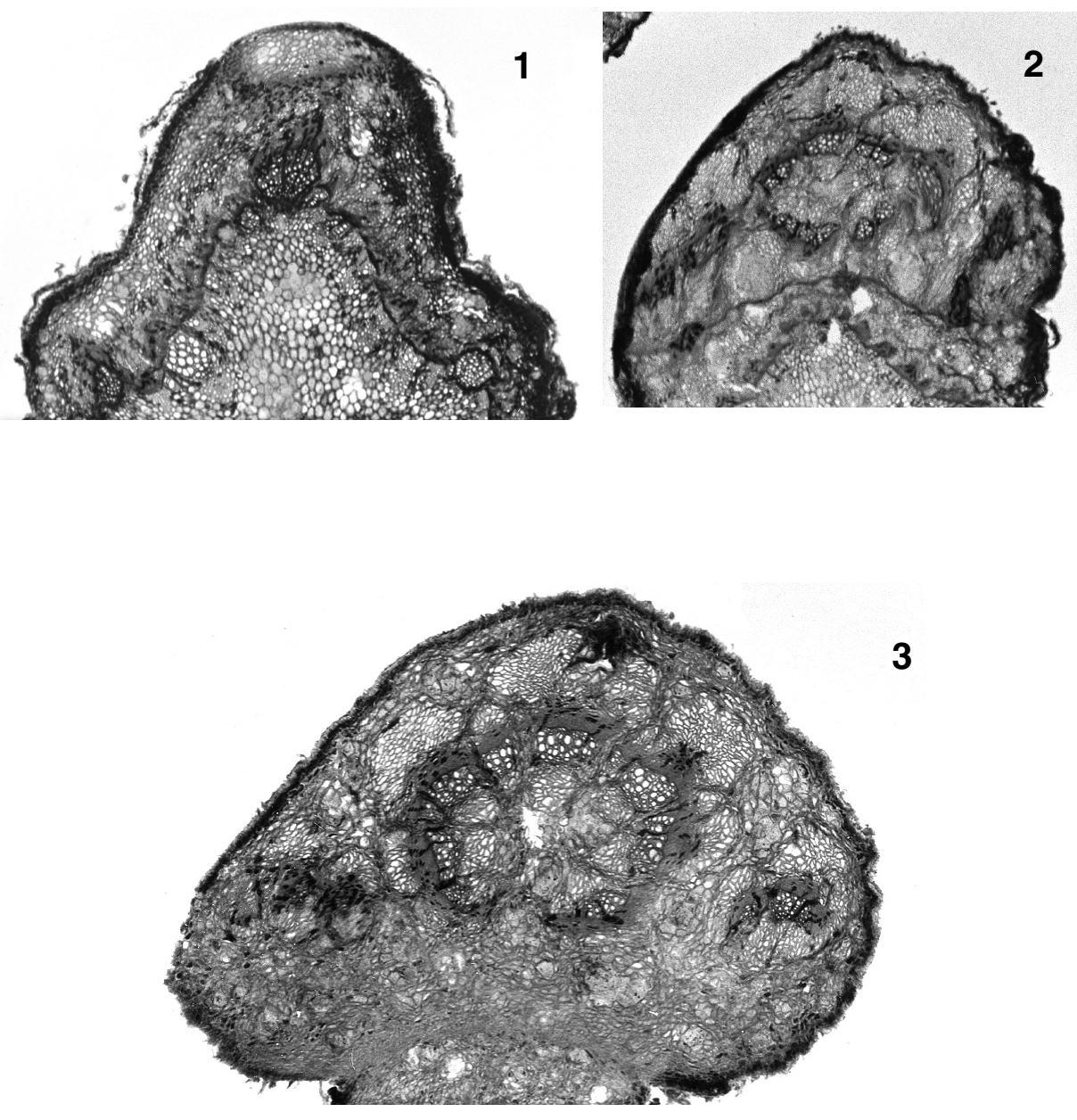

Fig 1. Finschia chloroxantha (NGF9123); transverse section of node showing an abscission layer and the absence of cork. No sclerenchyma crosses the abscission layer. There is a weaklydeveloped fibre cap below where the median leaf trace crosses the abscission layer. (c. $\times 30)$.

Fig 2. Finschia chloroxantha (NGF9123); transverse section of leaf base showing the lateral leaf traces entering the petiole. Near the abscission layer, they form small vascular bundles on the margins of the leaf base, outside the main circle. There are numerous sclereids in the petiole and in the cortex of the stem, many in a broken line close to the adaxial side of the abscission layer. (c. $\times 25)$.

Fig 3. Finschia chloroxantha (NGF9123); transverse section of leaf base where the petiole separates from the stem; it contains a ring of small bundles. Bundles in the abaxial arc have welldeveloped abaxial fibre caps and smaller groups of adaxial fibres. Small groups of abaxial and adaxial fibres are associated with each inverted bundle. Towards each margin there are two or three closely associated small bundles. (c. $\times 30)$. 

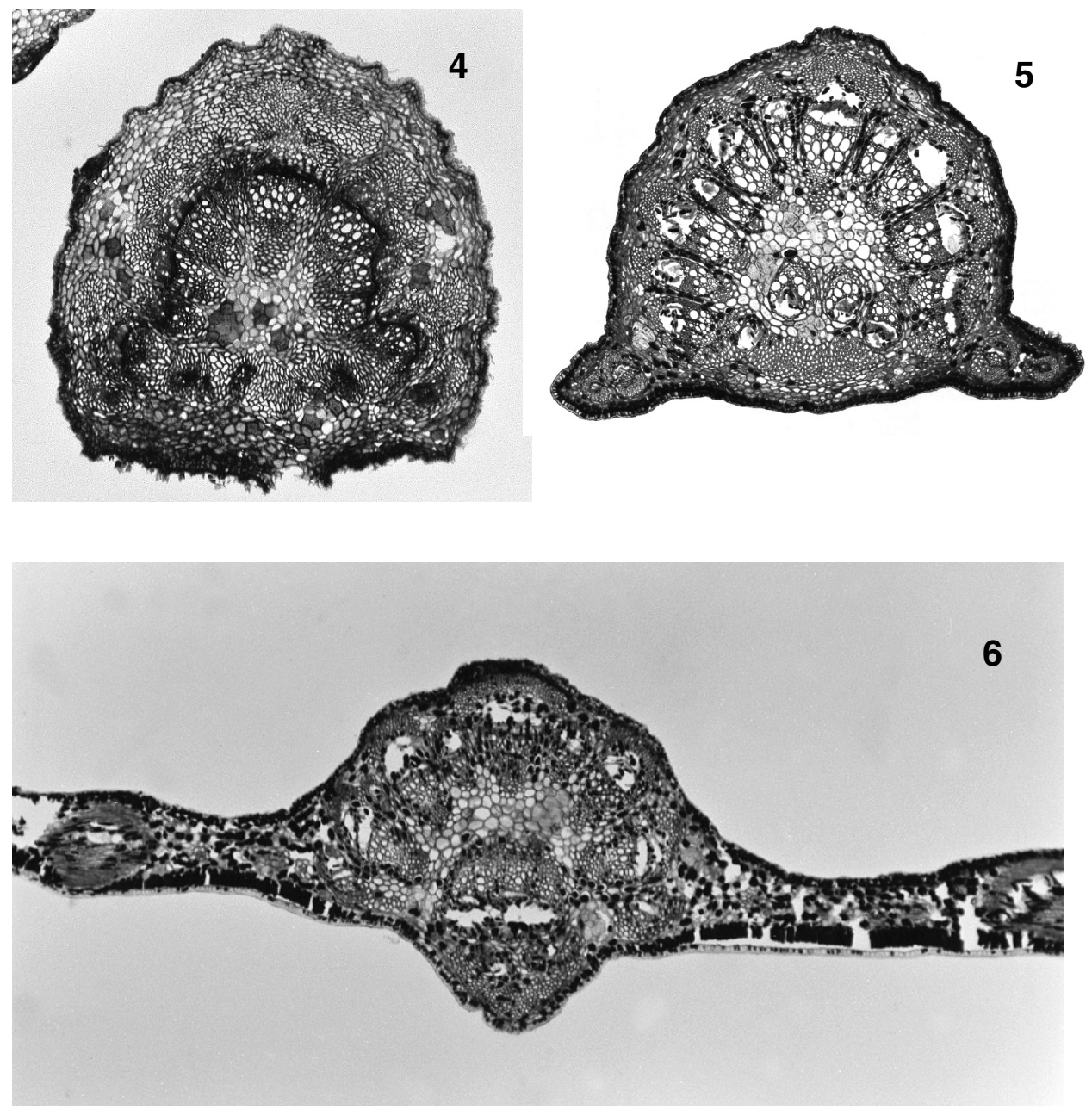

Fig 4. Finschia chloroxantha (NGF9123); transverse section of petiole; lateral bundles and bundles towards the abaxial surface are in a broad arc. Abaxial fibre caps are partially merged; adaxial fibres are in discreet groups. (c. $\times 30)$.

Fig 5. Finschia chloroxantha (NGF10358); transverse section of leaf base. Towards the distal end of the petiole, there are 2 adaxial marginal extensions. Two lateral bundles are separated from the main arc by unlignified parenchyma. (c. $\times 30)$.

Fig 6. Finschia chloroxantha (NGF10358); transverse section of midrib. All palisade cells contain tannin, some cell walls are lignified. Abaxial to the palisade, are 10-12 rows of mesophyll cells which are more spongy nearer the surface. One subepidermal row contains tannin. Main bundles are predominantly collateral with abaxial phloem. At the midrib, there is an abaxial arc of bundles of various sizes, each with an abaxial fibre cap. $($ c. $\times 30)$. 


\section{Leaf}

In outline, in transverse section, abaxial and adaxial surfaces were parallel. Margins were hardly recurved. The leaf was thicker over main veins. At the midrib, the abaxial side of the leaf was convex and there was a pointed adaxial ridge.

Leaves were dorsiventral. The abaxial epidermis consisted of a single row of irregularly rectangular cells. In surface view, anticlinal walls were sinuous. The stomata were brachyparacytic, only occurred on the abaxial surface and were not sunken below the general level of the epidermis. In the adaxial epidermis, cells were more regularly rectangular and anticlinal walls straighter. Outer epidermal walls were cutinised on the adaxial surface and at margins and more weakly cutinised on the abaxial surface. T-shaped hairs, similar to those in many members of the Hakeinae (Heide-Jorgensen, 1978) occurred on both surfaces. The bases of these were not sunken and they were mostly deciduous. There were small, occasional, collapsed glandular hairs. Some epidermal and mesophyll cells contained crystals.

In material collected by Powell and in NGF10358, palisade consisted of a single row of upright cells interrupted at main veins. In BSIP5577 and Akorra 238, cells were taller and narrower. In NGF9123, there was a second, irregular row of square cells. All palisade cells contained tannin. Some cell walls were lignified. There were pronounced pits in anticlinal walls. Abaxial to the palisade, were some 10-12 rows of mesophyll cells which were more spongy nearer the surface. One subepidermal row contained tannin.

Main bundles were predominantly collateral with abaxial phloem. At the midrib, there was an abaxial arc of bundles of various sizes, each with an abaxial fibre cap (Fig. 6). In all the specimens, there was some merging and dividing of fibres and vascular tissues. The number of bundles in the arc varied from 9-16. In three specimens there were 5 main bundles. In NGF10358 there were 9 bundles of more or less equal size and, in NGF9123 and BSIP183, there was considerable fusion of tissues. Adaxial fibres were associated with vascular groups. Bundles were separated by lignified parenchyma cells, some of which contained tannin. There were some 5-7 rows of abaxial unlignified cortical parenchyma; a morphologically distinct subepidermal row contained tannin. In NGF10358 and BSIP183, there were fewer rows of abaxial cortical parenchyma and, in NGF 9123, the subepidermal row was less distinct.

On the adaxial side of the midrib, there was a band of fibres (Fig. 7). In different specimens, cell walls were of different thicknesses and were more or less lignified. Among the fibres, there were occasional tracheary elements. Adaxial to the fibres were 2-3 rows of cortical parenchyma. In two specimens, NGF10358 and BSIP183, there were inverted vascular tissues on the abaxial side of adaxial fibres. In NGF10358, there was a tangentially spread group of inverted tissues and, adaxial to this, 3-4 bundles which were not precisely orientated. In BSIP183, there was some merging of inverted tissues which were seen as separate vascular bundles in the petiole.

Large unlignified or weakly lignified parenchyma cells filled the centre of the midrib and, among them, there were groups of large sclereids.

Towards the leaf margins, palisade was reduced and, close to the margin, there were small round parenchyma cells some of which contained tannin. A short distance from the margin, within the mesophyll, there were fibres and small vascular bundles (Fig. 8). Across the width of the leaf, bundles of various sizes had well developed abaxial and adaxial fibre caps. In the largest, fibres were separated from epidermides by 3 or 4 rows 

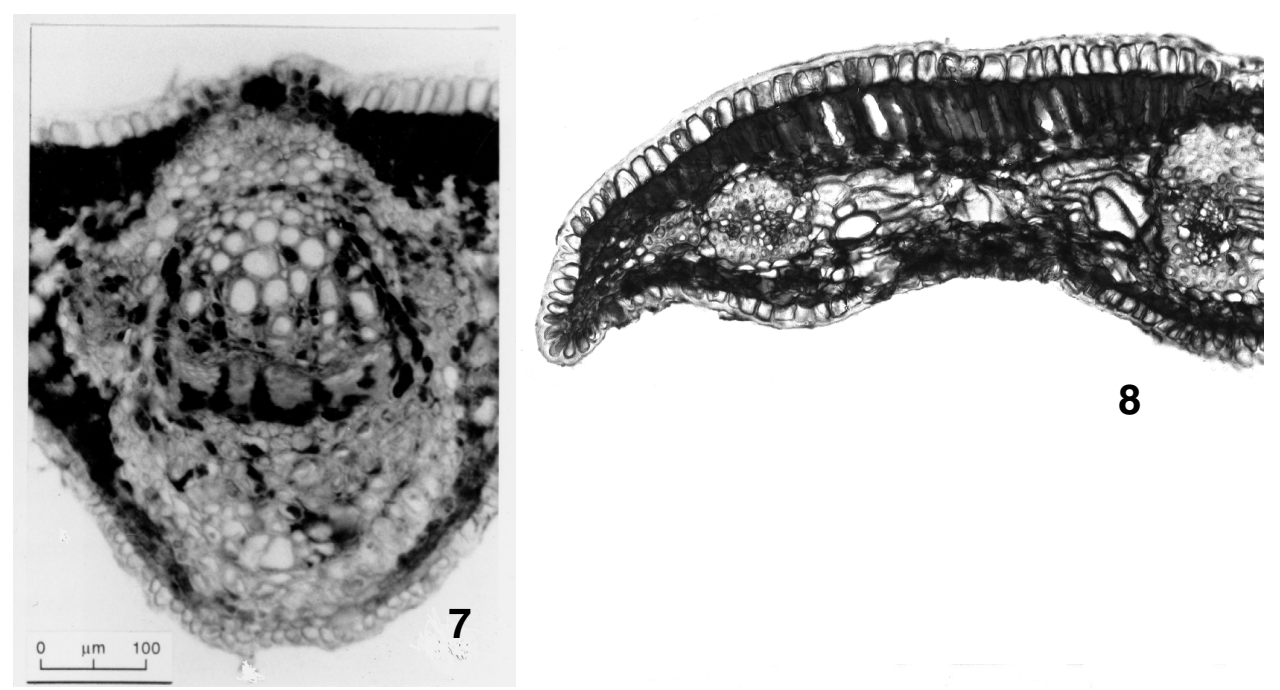

8
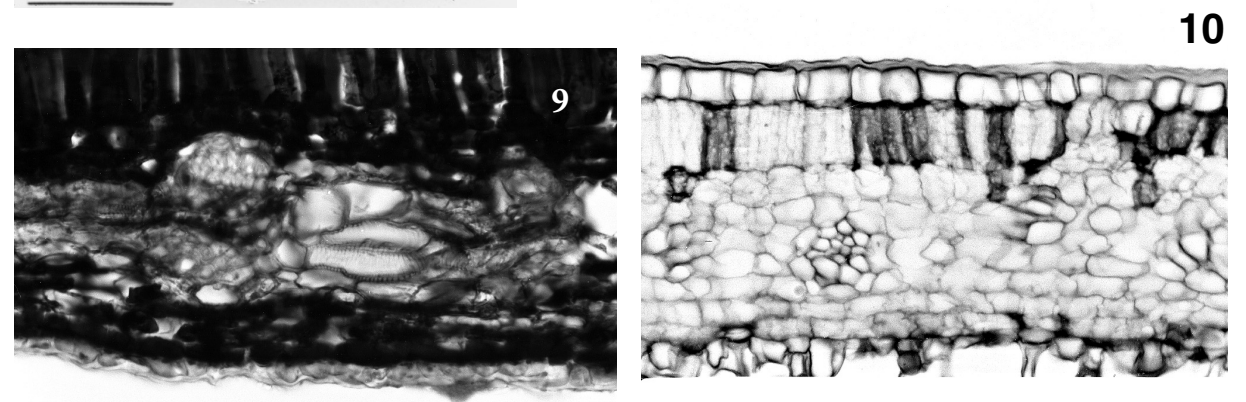

Fig 7. Finschia rufa (LAE59040); transverse section of main vein. Main bundles are predominantly collateral with abaxial phloem; there is an abaxial arc of bundles of various sizes, each with an abaxial fibre cap. There is some merging and dividing of fibres and vascular tissues. Adaxial fibres are associated with vascular groups. Bundles are separated by lignified parenchyma cells some of which contain tannin. On the adaxial side of the midrib, there is a band of fibres. $(c . \times 160)$.

Fig 8. Finschia chloroxantha (NGF9123); transverse section of leaf margin. Palisade is reduced towards the margins and, close to the tip, there are small round parenchyma cells some of which contain tannin. A short distance from the tip, within the mesophyll, there are fibres and small vascular bundles. $($ c. $\times 80)$.

Fig 9. Finschia chloroxantha (NGF9123); transverse section of leaf. Across the leaf, bundles of various sizes have well developed abaxial and adaxial fibre caps. In the largest, fibres are separated from epidermises by 3-4 rows of parenchyma. Near others, palisade is more or less modified. The smallest bundles are within the mesophyll. Large tracheary elements are associated with vascular bundles or occur in groups among mesophyll cells. $($ c. $\times 160)$.

Fig 10. Grevillea papuana (NGF38967) transverse section of leaf. Some heavily lignified palisade cells, some with irregular ends, intrude among other cells, and resemble columnar sclereids. (c. $\times 50)$. 
of parenchyma. Near others, palisade was more or less modified. The smallest bundles were within the mesophyll. Large tracheary elements were associated with vascular bundles or occurred in groups among mesophyll cells (Fig. 9).

\section{Finschia rufa}

The description below only records features in which F. rufa differed from F. chloroxantha. The description of F. chloroxantha can be used for other features.

\section{Node}

Hartley 13201 was a small specimen. One node was examined. At lower levels, in the position of one lateral leaf trace, there were two stelar bundles but these merged before leaving the stele. The specimen collected by Powell was larger. There was secondary thickening in the stem and petiole. Several adjacent nodes were examined. In all of them, there was a single stelar bundle associated with each leaf trace.

\section{Petiole}

In the material collected by Powell, where the petiole was separate from the stem, the abaxial arc contained 25-28 bundles and, in the adaxial line, there were 9 inverted bundles and 3 in which tissues were not precisely delimited and orientated. The arrangement of inverted bundles was similar throughout the petiole.

In Brass 25899, near the base of the petiole, there were one or two inverted bundles and one bundle in which tissues were not precisely orientated. Towards the lamina, there was one approximately inverted bundle on either edge of a broad adaxial band of fibres. In Hartley 13201, at the distal end of the petiole, inverted vascular tissues were not in collateral bundles; elements were dispersed among fibres and parenchyma.

\section{Transition from petiole to leaf}

In the material collected by Powell, in the midrib, in the lowest third of the leaf, there were inverted bundles. At higher levels, adaxial vascular tissues were randomly orientated or dispersed.

In Brass 25899 and Hartley 13201, within the leaf, inverted bundles were hardly recognisable.

\section{Leaf}

Abaxial epidermal cells were more or less rectangular and were covered with a close pattern of wax granules. Anticlinal walls were hardly sinuous. Especially over veins, on both surfaces, epidermal cells contained tannin.

On the adaxial surface, there were occasional, robust, T-shaped hairs. Over veins, hairs were more numerous.

The basal cells of hairs on the abaxial surface were similar to others in the genus but the two arms of the terminal cell were elongated and a persistent dense indumentum covered the surface.

No glandular hairs were seen in F. rufa.

In all the specimens examined, there was a weakly developed second row of square palisade cells. 
At the midrib, in Brass 25899, there were some 3-4 rows of abaxial cortical parenchyma. There was no distinct, subepidermal layer. There were no inverted bundles. In material collected by Powell, in sections from the centres of three leaves, there were occasional vascular elements among adaxial fibres but, in two leaves, there were three or four adaxial amphivasal bundles.

\section{Finschia ferruginiflora}

The description below only records features in which $F$. ferruginiflora differed from $F$. rufa.

\section{Petiole}

In available material, there were no inverted bundles. Towards the adaxial side, there was a broad band of well lignified fibres. Among the fibres, there were vascular elements.

\section{Leaf}

Abaxial epidermal cells were more or less rectangular. Anticlinal walls were hardly sinuous. Nearly all adaxial epidermal cells contained crystals. T-shaped hairs were occasional and often deciduous. Where complete hairs were seen, terminal cells were elongated and their walls were thin. No glandular hairs were found in F. ferruginiflora.

In Manner \& Street 255, there was a single row of tall, narrow palisade cells; some had lignified walls. Ends of cells were irregular and there was evidence of intrusive growth. On both sides of the spongy mesophyll, there were one or two rows of square, regular cells. These characteristics of the palisade and spongy mesophyll were present but not as distinct in Robbins 817.

Particularly in Manner \& Street 255, at the midrib, the subepidermal row of cells was not continuous and distinct and the central parenchyma was well lignified.

\section{Discussion}

It was possible to identify the three species in the genus using leaf epidermal features. The epidermal cells on the abaxial leaf surface of $F$. chloroxantha had distinctly sinuous anticlinal walls, whereas those of F. rufa and F. ferruginiflora were barely sinuous. Among the three species, the covering of wax granules on the abaxial surface was unique to F. rufa and glandular hairs were found only in F. chloroxantha. T-shaped hairs with elongated terminal cells formed a permanent dense indumentum on the abaxial surface of F. rufa. In F. ferruginiflora, there were persistent T-shaped hairs with elongated thin-walled terminal cells. The same epidermal features were consistent with the synonymy of F. rufa and F. carrii.

F. ferruginiflora and F. rufa grow in inaccessible habitats and, even in herbaria, specimens are few. It is desirable to examine more material to confirm the consistency of these features.

There were differences in palisade among the specimens examined but variation in F. chloroxantha and the plasticity of this feature generally made it inadvisable to attribute taxonomic significance to character states. 
There was within-species variability in the node and in the persistent or ephemeral inverted vascular bundles in the petiole and leaf. No nodal material of $F$. ferruginiflora was available and the short length of petiole in Manner \& Street 255 did not include the proximal region. In two specimens of $F$. rufa there were inverted bundles in the petiole but, in the lowest levels of the leaf, the tissues were dispersed. In material collected by Powell, inverted bundles were seen in the lowest third of the midrib. In five specimens of $F$. chloroxantha, there were inverted bundles at the proximal end of the petiole but, in material collected by Powell, this arrangement of vascular tissues was not seen at the distal end. At the centre of the leaf, inverted bundles were seen only in BSIP183 and NGF10358. Differences in structure were not associated with particular localities in this widely distributed species.

In nodes, modifications in more than one vascular bundle in the positions of some leaf traces might well have been symptoms of the frequent merging and dividing of stelar tissues rather than significant differences in the nodal pattern common to all the specimens examined. This does not necessarily exclude the taxonomic significance of multiple bundles at the generic level.

Finschia differs from Grevillea in having indehiscent drupaceous fruits, and Hakea is distinguished from Grevillea by its heavy follicular fruits, the pericarps of which have secondary thickening formed by cambial activity (McGillivray 1993). McGillivray quoted Weston (pers. comm.) who suggested that these features were derived, and this has been corroborated by unpublished molecular analyses on Grevillea, Hakea and Finschia (P. Weston pers. comm.). In Grevillea, most nodes had three lacunae (Catling \& Gates 1998) which raises the question whether the nodes in Finschia are apomorphic, having gained traces which gave rise to inverted bundles, or plesiomorphic with other members of the subtribe having lost these tissues. The presence of midribs with multiple bundles (including inverted bundles) is quite homoplasious within the family (Dillon 2002). Of all other species in the subtribe which have been examined (Catling \& Gates 1995a, b; 1998) only Hakea baxteri and H. brownii had nodes in which small stelar bundles were continuous with inverted bundles in the petiole and leaf. Within Hakea, these species were in the Obliqua group (Barker, 1990). The anatomy of the leaves of these Hakeas was different from the leaf anatomy of Finschia (Catling \& Gates 1995a). Hakea is generally accepted to be derived with respect to Grevillea. Even so, Finschia shares some anatomical similarities with Hakea.

Of 41 specimens of 30 taxa examined in Grevillea, there were additional bundles in the node in only two species. In G. insignis there were 4 lacunae and 4 traces and, in G. glauca, there were two stelar bundles in the position of each lateral leaf trace in two adjacent nodes. In 47 specimens of 31 species of Hakea, there were additional bundles in seven species.

In Hakea, inverted bundles occurred in the petiole, or leaf base, of 17 specimens of 10 species whilst, in Grevillea, they were found only in G. wickhamii, G. laurifolia, G. insignis and G. glauca. Although some anatomical characteristics of G. laurifolia were unlike other species of Group 1 in McGillivray's (1993) classification, taxonomists are convinced that the species is central in this group. Of the specimens examined in the genus, only G. wickhamii had inverted bundles in the midrib in sections from the centre of the leaf. In $G$. insignis, there were amphivasal bundles in the midrib complex. Taxonomically, G. laurifolia, G. wickhamii, G. glauca and G. insignis are not thought to be close to one another or to Finschia. 
In Finschia there was a concentration of sclereids close to the adaxial side of the abscission layer. Similar tissue patterns were found only in Grevillea insignis, G. sparsiflora, G. acuaria and G. pauciflora and in all the specimens from Groups 7 and 8 of McGillivray (1993) in which a complete node was examined. In Hakea, with the exception of H. linearis, the feature occurred in all the nodes studied. G. sparsiflora, G. acuaria and G. pauciflora are recognised to be closely related and have similar anatomy in which several features are different from other species in the genus (Catling \& Gates 1998). Group 8 included four species that share some unusual anatomical characteristics with some species of Hakea (Catling and Gates 1998). In Group 7, six species of Grevillea were examined. G. robusta, G. meisneri and G. papuana shared similarities, some of which were found in Finschia. G.robusta grows in rain forests and along creeks in Queensland and Northern New south Wales. G. papuana and G. meisneri are endemic to Papua New Guinea and New Caledonia respectively. G. glauca grows in Queensland and Papua New Guinea. It differs from other species in the group in having amphistomatic, isobilateral leaves and bundle sheaths which contained silica bodies. In spite of these differences, McGillivray (1993) placed G. glauca in this group. Unusually in the genus, but like some specimens of Finschia, G. glauca had additional bundles in the position of leaf traces in the node.

In G. robusta, G. papuana and G. meisneri, leaves were dorsiventral and shared similarities in structure (Catling \& Gates 1998) which, in their overall tissue patterns were similar to those in Finschia. In G. papuana, some heavily lignified palisade cells, some with irregular ends which intruded among other cells, resembled columnar sclereids (Fig. 10). This feature was seen also in G. glauca and in F. ferruginiflora, it was well developed in Manner \& Street 255. Columnar sclereids were not found in other species of Grevillea but were a consistent feature of Hakea (Catling \& Gates 1995b) especially in the Needlewoods and in the third sub division of the genus (Barker 1990). Although there were reorientated vascular tissues in the leaf bases of G. meisneri and G. robusta, the examination of series of sections showed that they were not homologous with inverted bundles in Finschia.

This examination of the anatomy of Finschia was a part of early studies to investigate some groups of the Proteaceae in which leaf anatomy had not previously been described. Similarities between Finschia and some species of Grevillea, placed together in Group 7 in McGillivray's (1993) classification, would support the relationships among these taxa proposed by some taxonomists although the distinctly different nodal structure needs some explanation. Similarities shared by Finschia, some species of Hakea and species such as Grevillea insignis and G. wickhamii might be significant but it is necessary to study more species and more specimens before proposing hypotheses.

\section{Acknowledgments}

The author would like to thank Dr. Kevin Powell, formerly on the staff of the University of Technology, Lae, Papua New Guinea, who collected excellent, invaluable material of F. chloroxantha and F. rufa; I am most grateful. Also I thank the Director of the Royal Botanic Gardens, Kew, the former Keeper of the Herbarium, Dr Brian Stannard, and Mrs Sandy Atkins who allowed me to use the collections and helped me to find specimens. At the Jodrell Laboratory, Miss Mary Gregory gave me great assistance and Miss Anna Lynch continued to provide valuable literature information. Professor Pieter 
Baas supplied material of F. ferruginiflora from the Nationaal Herbarium Nederlands, Leiden. I thank Margaret Creighton for taking care of a difficult manuscript.

\section{References}

Barker RM (1990) New species, new combinations and other name changes in Hakea (Proteaceae). Journal of the Adelaide Botanic Gardens 13: 95-110.

Catling DM \& Gates PJ (1995a) Leaf anatomy in Hakea Schrader (Proteaceae) Botanische Jahrbücher für Systematik, Pflanzengeschichte und Pflanzengeographie 117: 153-172.

Catling DM \& Gates PJ (1995b) Nodal anatomy in Hakea Schrader (Proteaceae) Botanische Jahrbücher für Systematik, Pflanzengeschichte und Pflanzengeographie 117: 173-186.

Catling DM \& Gates PJ (1998) Nodal and leaf anatomy in Grevillea R.Br. (Proteaceae) Botanische Jahrbücher für Systematik, Pflanzengeschichte und Pflanzengeographie 120: 187-227.

Chattaway MM (1948) The wood anatomy of the Proteaceae. Australian Journal of Scientific Research (B) 1:279-302.

Conn BJ \& Damas KQ (2006+). Guide to Trees of Papua New Guinea (http://www.pngplants. org/PNGtrees)(viewed: 10 June 2010).

Diels L (1916) Beiträge zur Flora von Papuasien 5. Botanische Jahrbücher für Systematik, Pflanzengeschichte und Pflanzengeographie 54: 69-261.

Dillon RA (2002) The diversity of scleromorphic structures in the leaves of Proteaceae. Unpublished BSc Hons thesis, University of Tasmania, Hobart.

Foreman D (1995) Finschia in: BJ Conn (ed.) Handbook of the flora of Papua New Guinea. (Melbourne University Press: Melbourne)

Furuno T (1977) Anatomy of Papua New Guinea woods. Research Report of Foreign Wood 6: $1-92$.

Heide-Jorgensen HS (1978) The xeromorphic leaves of Hakea suaveolens R.Br. I. Structure of photosynthetic tissue with intercellular pectic strands and tylosoids. Botanisk Tidsskrift 72: 87-103.

Ilic J (1991) Atlas of Hardwoods. (Crawford House Press: Bathurst, Australia)

Johnson LAS \& Briggs BG (1975) On the Proteaceae - the evolution and classification of a southern family. Botanic Journal of the Linnean Society (London) 70: 83-182.

Lauterbach C (1913) Beiträge zur Flora von Papuasien III. Botanische Jahrbücher für Systematik, Pflanzengeschichte und Pflanzengeographie 50: 288-383.

McGillivray DJ (1993) Grevillea (Proteaceae) a taxonomic revision. (Melbourne University Press: Melbourne)

Metcalfe CR \& Chalk L (1950) Anatomy of the Dicotyledons. (Oxford University Press: Oxford)

Sleumer H (1939) Beiträge zur Flora von Papuasien 24. Botanische Jahrbücher für Systematik, Pflanzengeschichte und Pflanzengeographie 70: 95-148.

Streimann H (1969) Photomicrographs of the wood and some commercial timbers of the Territories of Papua and New Guinea. Papua and New Guinea Forestry College, vol. 4. (Australian Government Printer, Canberra)

Warburg O (1891) Beiträge zur Kenntnis der papuanischen Flora. Botanische Jahrbucher für Systematik, Pflanzengeschichte und Pflanzengeographie 13: 230-455.

Weston PH \& Barker NP (2006) A new suprageneric classification of Proteaceae, with an annotated checklist of genera. Telopea 11: 314-344.

White CT (1949) Finschia - a genus of "nut" trees of the southwest Pacific. Pacific Science 3:187194. 


\section{Appendix A. Specimens Examined}

Legend: $\mathrm{F}=$ Finschia; $\mathbf{G}=$ Grevillea. Regions examined: 1 = Stem, 2 = Node, 3 = Petiole, 4 = Centre leaf, $5=$ Leaf margin

\begin{tabular}{|c|c|c|c|}
\hline Species & Collector & Location & Regions examined \\
\hline \multirow[t]{6}{*}{$\begin{array}{l}\text { F. chloroxantha } \\
\text { Diels }\end{array}$} & K. Powell s.n. & $\begin{array}{l}\text { Unitech. Campus, } \\
\text { University of Technology, } \\
\text { Lae, Morobe, PNG }\end{array}$ & $1,2,3,4,5$ \\
\hline & $\begin{array}{l}\text { K.J. White } \\
\text { NGF10358 }\end{array}$ & $\begin{array}{l}\text { Oriomo River, Western, } \\
\text { PNG }\end{array}$ & $3,4,5$ \\
\hline & $\begin{array}{l}\text { J.J. Havel \& } \\
\text { J. Dobson } \\
\text { NGF9123 }\end{array}$ & Bulolo, Morobe, PNG & $1,2,3,4,5$ \\
\hline & $\begin{array}{l}\text { Whitmore Collection } \\
\text { BSIP5577 }\end{array}$ & $\begin{array}{l}\text { Baga Island, New Georgia } \\
\text { Group, Solomon Islands }\end{array}$ & $1,2,3,4,5$ \\
\hline & $\begin{array}{l}\text { R.S. Walker \& } \\
\text { C.T. White } \\
\text { BSIP183 }\end{array}$ & $\begin{array}{l}\text { Kolombangara Island, } \\
\text { New Georgia Group, } \\
\text { Solomon Islands }\end{array}$ & 3,4 \\
\hline & Akorra 238 & No locality & 4,5 \\
\hline \multirow[t]{2}{*}{ F. rufa Warb. } & K. Powell s.n. & $\begin{array}{l}\text { Bulolo Forestry College, } \\
\text { Morobe, PNG }\end{array}$ & $1,2,3,4,5$ \\
\hline & S. Isles LAE59040 & $\begin{array}{l}\text { S of Manumu village, } \\
\text { Central, PNG }\end{array}$ & 5 \\
\hline \multirow[t]{2}{*}{ F. rufa Warb. } & Brass 25899 & $\begin{array}{l}\text { Waikaiuna, Normandy } \\
\text { Island, Papuan Islands, PNG }\end{array}$ & $3,4,5$ \\
\hline & & $\begin{array}{l}\text { T.G. Hartley } 13201 \\
\text { Near Perosa, } \\
\text { c. } 18 \text { miles SW } \\
\text { of Okapa, Eastern } \\
\text { Highlands, PNG }\end{array}$ & $1,2,3$ \\
\hline \multirow[t]{2}{*}{$\begin{array}{l}\text { F. ferruginiflora. } \\
\text { C.T White }\end{array}$} & R.G. Robbins 817 & $\begin{array}{l}\text { Asaro Valley, Eastern } \\
\text { Highlands, PNG }\end{array}$ & 4 \\
\hline & $\begin{array}{l}\text { H. Manner } 225 \text { \& W. } \\
\text { Street }\end{array}$ & $\begin{array}{l}\text { Jimi valley, Western } \\
\text { Highlands, PNG }\end{array}$ & $3,4,5$ \\
\hline G. papuana Meisn. & $\begin{array}{l}\text { E.E. Henty, R. Isgar } \\
\text { \& M. Galore } \\
\text { NGF38967 }\end{array}$ & $\begin{array}{l}\text { Oksapmin, West Sepik, } \\
\text { PNG }\end{array}$ & $3,4,5,6$ \\
\hline
\end{tabular}


